view to suggesting some explanation of the extraordinary asymmetry of the latter. Mr. Willey thinks that a cause of the one-sided position of the mouth and of the primary series of gill-slits in the Amphioxus larva may be found in the excessive anterior prolongation of the notochord at an early period of development, necessitating a pushing to either one side or the other of the mouth. There appears to be nothing in the mode of life of the larvaa free-swimming ciliated creature-which can be correlated with its asymmetry. The gradual process of "symmetrization," by which the Amphioxus establishes more or less completely a bilateral symmetry on its way to the adult form, is exactly the converse of that process by which the symmetrical larva of the Pleuronectid fishes becomes one-sided; but in the latter case the asymmetry is clearly correlated with a peculiar life on the sea bottom, whilst in the former case we can discover no such relation to environment.

E. R. L.

\section{THE CARDIFF MEETING OF THE BRITISH ASSOCIATION.}

TO arrange for the reception of the members of the British Association who will visit Cardiff in August next, an influential Local Committee has been formed, with the Most Honourable the Marquis of Bute, K.T., Mayor of Cardiff, as Chairman, and a substantial sum has been subscribed for the purpose of defraying the cost of the meeting.

Several sub-committees have been formed, all of which report to the Executive Committee, to which also the Council of the British Association has assigned the duty of electing new members and associates. Up to the present time 7 life members have been added, and over 200 annual members and associates, and as the time for the meeting approaches the number of new members and associates will be largely increased.

It may be convenient to describe what has been done by the sub-committees, so as to give a systematic account of the preparations already made and in progress to provide for the comfort and entertainment of our expected visitors.

(I) Hospitality and Lodgings.--Many of the principal residents in Cardiff and the neighbourhood have signified to the Committee their desire to entertain members of the Association, and as the date of the meeting draws nearer numerous additional offers will be made by those of the townsmen who are unwilling or unable to fix their engagements so long beforehand. It is understood that those ladies and gentlemen who have offered to invite guests will send out invitations as soon as it is known to the Committee who are coming.

The hotel and lodging accommodation is not so great as in some other towns, but the Committee feel sure that with the private hospitality which will be offered there will be enough for the needs of our visitors. The list of hotels and lodgings will be ready for distribution about the middle of July, it having been delayed to make the list as complete as possible. The list will be accompanied by a map of Cardiff taken from the most recently executed ones.

(2) Reception and Section Rooms.-The reception room will be at the Town Hall, practically the whole of which has been placed at the disposal of the Local Committee for the use of the Association. The vestibule will be devoted to the sale of tickets, the distribution of programmes, and other information, whilst the Assembly Rooms will be fitted up as a drawing-room with writingtables, post-office facilities, and a book-stall. The Council, Committee of Recommendations, and General Committee will meet in various rooms, and others will be set apart for the officers of the Association.

As the Town Hall is about half a mile from the Section room furthest away, a portion of the Drill Hall, the use

NO. I I 3 I, VOL. 44$]$ of which has been kindly granted by Lord Bute, Colonel Gaskell, and Colonel Page, will be fitted up as a drawingroom, and the remainder will be used as a luncheonroom. As the Drill Hall is situated within very easy distance of almost all the Section rooms, the members of the Association will doubtless appreciate the advantage of having a drawing-room and dining-room so clese at hand.

The majority of the Section rooms are very close together, and the greatest distance is not more than half a mile; tramcars and busses, however, run frequently between the extreme points, so that even that distance should offer no difficulty in the way of members wishing to attend different Sections.

(3) Entertainments.- The usual conversazioni will be given on Thursday, August 20, and on Tuesday, the 25 th, and it is hoped that scientific men will aid the Committee in contributing towards the entertainment of our guests by the exhibition of novel experiments or specimens. The Park Hall, in which the conversazioni will be held, is well suited to this purpose, and it is the desire of the Committee to introduce as many scientific novelties as possible.

A garden party, to which all members of the Association will be invited, will be given by Lord and Lady Bute, probably on the Friday afternoon, though the date may be subject to alteration. Other social entertainments are projected by Lord Windsor and others, and Cardiff will probably in this respect not fall behind what the members have been accustomed to at other places of meeting.

(4) Excursions.-A considerable variety of excursions has been provided for both the Saturday and the following Thursday. For the former, arrangements are being made by $\operatorname{Sir}$ W. T. Lewis for a party of members to visit the Cardiff Docks; by a committee appointed by the Board of Directors to visit the Barry Docks; by the Mayor of Newport and the Chamber of Commerce for a party to visit Newport and Caerleon. A special excursion is being arranged by the Colonel commanding the Severn Valley division of submarine miners for officers of the British Army to inspect the Severn Valley defences. The steamer will land the officers at the steep and flat holmes, and will continue with the civilians on board to Weston, from which they will visit Worlebury Hill and camp.

Other excursions will be of geological and archæological interest, and will include excursions to Penarth and Lavernock, where the finest section of Rhætic beds in England is exposed; to the interesting dolmens at St. Nicholas and St. Lythan's; to Llantwit-major, where a year or two ago the remains of a Roman villa were unearthed, and where a college is said to have existed in the fourth century; to Tintern Abbey and Raglan Castle, the Forest of Dean, Merthyr, Brecon, and to some of the numerous collieries and iron-works in the South Wales coal-field. A practical natural history excursion is being organized by the Cardiff Naturalists' Society to the Vale of Neath, which from the beauty of the spot should prove attractive. Several owners of works in the neighbourhood of Cardiff have expressed their willingness to throw them open to the members, and arrangements will be made for visits to some of them.

(5) Publications.-A guide-book to Cardiff is being prepared for distribution to all members and associates, and the descriptive articles have been intrusted to the gentlemen who were best fitted to write them. The article on the history and archæology of Glamorganshire has been written by the veteran G. T. Clark, of Dowlais, whilst that on the topography of Cardiff was undertaken by the late James A. Corbett, who, unfortunately, died before it was quite complete. Mr. T. Forster Brown, President of Section $G$, has undertaken the description of the mining, geological, and statistical features of the district; the industrial portion being in the hands of Mr. 
Galloway. The geological, zoological, and botanical descriptions have been written by Mr. T. H. Thomas and Prof. W. N. Parker, with the help of many others. The account of the educational arrangements of Cardiff will be treated of by Mr. Whitmell, Inspector of Schools, and Principal J. V. Jones.

The excursions hand-book will contain a map, on a scale of four miles to the inch, of the whole of the district in which the excursions will be held, specially prepared for the Committee by Messrs. Bartholomew and Co. Edinburgh. As detailed accounts as possible of the various points to be seen in the excursions will be given by those having special knowledge: taken together with the guide-book, it is thought that a very complete description of everything connected with this portion of South Wales will be furnished to the visitors.

Other Committees have been formed for the evening lectures and the working men's lecture, but little more can be said about them than that they will provide to the fullest extent for the wants of the Association. The Local Committee are anxious that this shall be the case in every particular, so that the first visit to the metropolis of Wales will not suffer in comparison with previous meetings of the Association.

R. W. ATKINSON.

\section{MARINE BIOLOGICAL ASSOCIATION OF THE UNITED KINGDOM.}

W

have received the annual report of the Council of this Association, presented at the general meeting on June 24-the President, Prof. Ray Lankester, F.R.S., in the chair. In the sea, as well as on land, the severe winter appears to have bad a marked effect on the fauna, and there is also a complaint of mortality in the aquarium attached to the Laboratory during the colder months; a result perhaps somewhat unexpected, considering the comparatively high winter temperature of the sea. We are glad to learn that a self-sown fauna is springing up in the tanks, the condition of which is said to be steadily improving, as is the case with all aquaria after one or two years of use.

Under the head of the library (which ought to be represented in the balance-sheet by a larger sum than is at present debited to it) the Association is to be congratulated on having received the gift of the late Mr. Spence Bate's library, constituting an exceedingly valuable collection of the literature of Crustacea.

Some of the changes made in the permanent staff have been chronicled already: Mr. Calderwood has replaced Mr. Bourne as Director, and has appointed Mr. H. N. Dickson to succeed Mr. Garstang, who took up a Fellowship at the Owens College in December last. Two temporary members have been added to the staff: Mr. F. Hughes, to carry out from the chemical point of view an inquiry into the possibility of manufacturing an artificial bait; Mr. E. W. L. Holt, known already as the author of some papers on Teleostean development, to conduct investigations into the immature fish question as regards the Dogger Bank and the region eastwards of itthe lines of this latter inquiry are sketched in an appendix to the report. Among the fishery investigations of the past year are quoted experiments on the rate of growth and the age of sexual maturity in food-fish, oyster and lobster culture, and the anchovy fishery which the Association desires to initiate. We are glad to see that systematic physical observations are to be taken at the Laboratory in future.

Eleven gentlemen have visited the Laboratory during the year for the purposes of research, some of them on more than one occasion. This number, however, is by no means as large as it should be.

The balance-sheet shows a satisfactory, if small, increase in receipts, the items pointing to an increased use NO. I I 3 I, VOL. 44 ] of the Laboratory, both for research and for the purchase of material for teaching purposes. A sum of $£, 500$ (in addition to the annual grant of $£ 500$ ) has been placed on the Civil Service estimates for the current year, which will, if passed, place the Association in a position to carry on its work with less difficulty than has hitherto been the case.

\section{UNIVERSITY EXTENSION STUDENTS AT $C A M B R I D G E$.}

THE work done by University Extension students at Cambridge last year was so satisfactory that the Syndicate for local lectures are encouraged to repeat the experiment this year. They will be prepared to receive a larger number of students, say from 60 to 80 , most of whom will be lodged either at Selwyn College or at Newnham College. The period of study will last from July 28 to August 22, or nearly a month in all. The Syndicate have just issued a detailed programme of the various courses of study; and we are glad to see that due attention has been paid to the claims of science as well as to those of literature and art. At the chemical laboratory, on alternate days, there will be a course of demonstrations illustrating the methods of chemical manipulation in a short series of typical experiments. The pupils will be first shown each experiment, and will then be expected to repeat it for themselves. At the Cavendish Laboratory, on alternate days, a course of short experimental lectures, chiefly on electricity and magnetism, will be delivered; and most of the experiments shown in the lectures will afterwards be performed by the students for themselves. Geology will be studied, on alternate days, at the Woodwardian Museum, where there will be a course of demonstrations on the leading fossil types of the animal kingdom, from the specimens in the Museum. A course of demonstrations, followed by practical work, will be given, on alternate days, in the physiological laboratory; and Mr. Graham, chief assistant at the Observatory, will receive students and explain the uses of astronomical instruments. Arrangements will also be made for taking small parties of students to the Observatory at night. Single lectures will be delivered by various eminent Cambridge men, and in this part of the work science will be represented by Prof. G. H. Darwin, who will lecture on the history of the moon or some allied subject. We may note that the students in science will be allowed to read in the Philosophical Library.

\section{NORMAN R. POGSON, C.I.E.}

$\mathrm{W}^{\mathrm{E}}$ regret to have to announce the death of $\mathrm{Mr}$. Norman Pogson, for thirty years the Director of the Observatory at Madras. Mr. Pogson has been so long absent from England that, in a sense, he may be said to have outlived his reputation; but those who can recall the condition of astronomy in this country some thirty years since will remember him as a rising astronomer of considerable promise, and as one of the most indefatigable observers at that time. If his subsequent career has not entirely fulfilled his early promise, perhaps the condition of the Madras Observatory is to some extent the cause. We believe that its astronomical equipment is very old and inadequate, and possibly Mr. Pogson has accomplished all that could be done with his instruments and his staff.

Mr. Pogson's astronomical career commenced at $\mathrm{Mr}$. Bishop's Observatory in Regent's Park, at that time under the direction of Mr. J. R. Hind, and he there took part in the observations for forming the ecliptic charts published from that Observatory. In I 85 I he left London 